\title{
OPINION
}

\section{Human Rights Activism and the Politics of Smell and Noise*}

\author{
Marieke Borren
}

Talking about 'the rights of those who have no rights,' Jacques Rancière argues that those groups who have no full rights - including 'illegal' immigrants and second-class citizens, primarily, in his examples, women and workers - should act as if they are already part of the 'we' of the people, and act as if they already have those rights they formally cannot claim, rather than wait for these rights to be given them. He describes such practices of claiming human rights and democratic agency as 'making visible what had [formerly] no business being seen, and mak[ing] heard a discourse where once there was only place for noise. ${ }^{1}$ However, are the struggles for human rights of those with a precarious legal standing only legitimate if the latter have a 'good story' to tell? And what counts as a good story, and who decides about it, for that matter? In other words: who has the authority to tell 'noise' from 'discourse', on what grounds?

For me, these questions were provoked when I was working as a postdoctoral fellow at the University of Pretoria and closely witnessed the \#MustFall student protests evolving in South Africa in late 2015. The protests had kicked off when a student poured human excrements over the statue of British colonialist and mining tycoon Cecile John Rhodes at the campus of the University of Cape Town on March 10 of that year, wearing a banner stating Exhibit White Arrogance. Throughout the country, mostly black and colored students of the so-called 'Born Free' generation, growing up after the transition from Apartheid to democracy, subsequently started mobilizing around a number of causes. Using the slogan \#MustFall, they demanded the decolonization of curriculums and campuses, the transformation of the language policy at those universities that still prescribed Afrikaans as the medium of instruction, the freezing of the announced tuition fee hikes or even the right to free tertiary education, and an end to the near-universal practice of outsourcing cleaning tasks at South African universities. The almost entirely peaceful though noisy rallies (students everywhere engaged in toyi toyi, the typically South African protest songs and dances that were developed under Apartheid) provoked euphoric reactions in the liberal media. On October 23, the triumphant headlines of Mail \& Guardian, South Africa's quality newspaper, read:

* This article has been written with the support of postdoctoral funding by the University of Pretoria, South Africa.

1 Jacques Rancière, Dis-agreement: Politics and Philosophy (Minneapolis: University of Minnesota Press, 1999), 30. On 'the rights of those who have no rights,' also see Jacques Rancière, 'Who is the Subject of the Rights of Man?,' South Atlantic Quarterly 2/3 (2004): 297-310. 
Free for all. History will remember them as the generation who would no longer be quiet. Indeed, the fees were frozen (at least for the academic year commencing from January 2016), and Vice Chancellors of the major universities announced a policy of 'insourcing' cleaners and gardeners. In July 2016, the universities of Pretoria and Stellenbosch, the last to conduct a language policy that privileged Afrikaans, finally agreed to switch to multi-lingual education.

At the height of the student protests, I was working from a flat in downtown Johannesburg, my then place of residence, in an unbearable noise and smell of waste. The municipal garbage collectors had been striking for weeks. From my flat I watched a chaotic multitude of intimidating looking workers, who were carrying sjamboks and simply any stick they could lay their hands on to destroy garbage bags and spread waste like peanut butter on the pavements and streets; the very same sticks they used as drum sticks on garbage containers. As the strikes had been going on for weeks, waste piled high, which attracted rats, occasionally took fire and caused an awful smell in the midst of one of the warmest and driest summers ever in South Africa.

I noticed several similarities between these two incidents of activism. Both the students' and the garbage collectors' protests primarily dealt with socio-economic issues, respectively high college fees, and low wages. Both groups employed smell (human excrement, rotting and burning waste) and noise (toyi toyi and drum rolls on waste containers) as a means to draw attention to their cause.

The differences stood out, though. The \#Must Fall protests put the fee issue in a wider context. As one student put it: 'It is not about Rhodes, outsourcing, fees (...) it is about defining a new society for all South Africans (...) This movement is a call for (...) a new vocabulary, structural and institutional renewal (...) The response, until now, has been a day-to-day strategy, focused on "resolving" one problem at a time and keeping a low profile until the movement wanes. That is the way administrators conduct their business; but this time, this strategy has failed.' ${ }^{2}$ In contrast, I was initially not even sure what the waste protests actually were about. The garbage collectors did not carry banners, sing protest songs, post discussions on Internet forums or make up hashtag slogans. Only much later did I learn that they demanded decent wages and working conditions. Like the students, they produced smell and noise, but unlike them the garbage collectors did not 'make themselves heard' by turning their discontent into a story, let alone a good one. Yet, did it necessarily rob their protests of legitimacy? I started wondering. When is a big mouth seen as an expression of eloquence, and when as merely bawling? Why was the \#MustFall campaign seen as a 'studied chaos' and the rallies of the garbage collectors as merely disorder?

For liberal political and legal theorists (including their deliberative next of kin), the legitimacy of human rights struggles usually depends on the quality of the

2 Vissého Adjiwanou, 'It is not about Rhodes, outsourcing, fees (...) it is about defining a new society for all South Africans,' Mail \& Guardian, October 26, 2015. 
story told, while a good story is a reasonable one in the light of the universal principles of human rights (what is reasonable is of course a matter of dispute among liberal theorists). For those theorists outside of the liberal mainstream, this issue is more complex. What is at stake here are fundamental questions about the nature of normativity, given the persistence of unequal power relations.

\section{Translation}

In her recent book, Rightlessness in an Age of Rights. Hannah Arendt and the Contemporary Struggles of Migrants (2015) the American political theorist Ayten Gündoğdu argues that those with a precarious legal position should tell, not reasonable stories, but imaginative ones that translate their particular interest into more general concerns. She demonstrates that certain liberal cosmopolitan accounts ignore the potential adverse consequences of the human rights framework. Following Hannah Arendt's account of the predicament of stateless refugees in interwar Europe, she reminds liberal theorists of the existence of an inescapable 'antinomy between law and institutions': 'Rights are in need of artificial inventions such as laws and other institutional structures to offer effective guarantees of equality and freedom. However, the institutions that we establish in order to have relatively permanent guarantees can end up destroying these rights. ${ }^{3}$ Also, established legal institutions may be unjust and unresponsive to demands for new rights, whence Gündoğdu's caution regarding an institutionalist approach of human rights in liberal theory. The precarious legal personhood of, particularly, refugees, asylum seekers and undocumented immigrants is a case in point, as is evident from the proliferation of detention and deportation as routine solutions to the problem of failed asylum seekers and undocumented migrants and from the fact that encampment is becoming a protracted condition for ever larger groups of refugees.

Gündoğdu alerts the reader to the contingency and ambiguity of the trajectories of human rights norms and institutions: they emerged and developed in particular historical circumstances and may be appropriated in different and unpredictable ways - for better or worse. This presents us with the continuing political task of reimagining and reenacting human rights. Human rights are permanently in need of citizens' and non-citizens' agonistic political action, first and foremost the struggles and collective action by the rightless themselves, involving 'translation' and (re-)founding and inventing of human rights. ${ }^{4}$ Outsiders - usually citi-

3 Ayten Gündoğdu, Rightlessness in an Age of Rights. Hannah Arendt and the Contemporary Struggles of Migrants (Oxford: Oxford University Press, 2015), 43. This 'antinomy' or 'perplexity' is widely discussed in recent democratic theory in terms of the paradox of law and politics within such highly divergent paradigms as deliberative democracy (Seyla Benhabib and Jürgen Habermas among others) and agonistic pluralism (most notably Bonnie Honig and Chantal Mouffe), to different effects.

4 On the law that perpetually needs the supplement of democratic civic action, also see Bonnie Honig, Emergency Politics. Paradox, Law, Democracy (Princeton, NJ: Princeton University Press, 2009). 
zens who are in a much better legal position - should not represent the rightless, and appropriate their cause. 'Translation' means representing a problem as a matter of common concern. In this context, Gündoğdu offers a rereading of Arendt's highly contested distinction between social and political concerns. She takes a performative or practical perspective on the distinction by arguing that it calls forth the need to politicize human rights issues. No issue is a priori exempt from such translation. Poverty, most notably, is not in itself a social problem (the conventional interpretation of Arendt's take on what she calls 'the social question'), but may be addressed in either political or anti-political ways. Elsewhere, I have argued that this requires a Gestaltswitch from a social to a political perspective on problems. ${ }^{5}$

By practices of 'founding,' Gündoğdu, like Rancière, refers to the acts of declaration of new human rights by the rightless themselves, her prime example being the Sans Papiers movement. It entails imaginative practices of reenacting the principle embodied in prior declarations which may give rise to new rights and legal subjects.

\section{Might makes right}

The \#MustFall student protests are an excellent example of Gündoğdu's practices of translation. The students effectively and inventively translated the fee issue a social matter - into political issues in the Arendtian sense. They deliberately and self-consciously employed the human rights discourse and even claimed the not (yet) existing human right to free higher education. The garbage collectors, on the other hand, failed to turn their social into a political struggle.

Is the 'politics of translation' elitist? The students' cultural and intellectual capital compensated for their lack of social-economic capital, since it allowed them to put poverty and unequal access to higher education and the labor market on the agenda. However, not everyone has the same level of skills for mobilizing the media in an articulate way. The majority of the rallying garbage collectors had no or a low level of education and, being at the very bottom of a labor market without a minimum wage, their livelihoods were precarious, which seemed to be the reason for their activism. Were the students being listened to, just because of their superior eloquence in voicing their concerns and group branding skills in enhancing human rights, if compared to the garbage collectors? Are we standing on feet of clay?

This is indeed affirmed by many scholars working in critical legal theory, postcolonial theory, and some varieties of neo-Marxist thought. The human rights skeptic says: it is all about power and petty interests. Which claims are legitimate and count as human rights, and which not, is simply decided by those groups which

5 Marieke Borren, 'Feminism as Revolutionary Practice. From Justice and the Politics of Recognition to Freedom,' Hypatia. A Journal of Feminist Philosophy 1 (2013): 97-214. 
happen to be powerful: a particular class (the middle and higher classes), intellectual elite ('left-wing church'), ethnic group ('white hegemony'), or geopolitical region ('the West' which determines that crimes against humanity are solely committed by Africans). Social movements fail to bring about fundamental transformations but merely replace the powers that be with their own particular interests, skeptics hold. Whoever is unable to translate her discontent into the alleged 'common good' - which is in fact no more than the good of dominant groups - is simply not (yet) ready or willing to play along. Distinguishing between effective and legitimate protest itself is the result of the ideological stupor that liberal thinkers have fallen prey to, and merely serves to conceal that whoever shouts loudest is proved right. So-called universal human rights are no more than sweet lies and hypocritical excuses or alibis for the powerful to tend to their own group interests. No one has voiced this argument with as much sarcasm as the ultraconservative legal theorist Carl Schmitt, who wrote in 1932: “Menschheit" ist ein besonders brauchbares ideologisches Instrument imperialistischer Expansionen (...) Wer Menschheit sagt, will betrügen.' ${ }^{6}$

Although there is some truth to this radical critique of human rights, it easily gives rise to a cynicism that I find sinister and politically unproductive. I agree with Gündoğdu that although we may not have a rock bottom beneath our feet - a universally valid principle or foundation such as a 'common humanity' - this does not mean that human rights claims are normatively void. What I find particularly powerful is how she demonstrates that many human rights cynics ignore the ambiguity of the discourse and history of human rights. The French declaration of human rights of 1789 indeed set in motion the Jacobin Terror, but it also inspired the Paris Commune, for example. Human rights declarations do not inevitably end up in rightlessness and sovereign violence, as for example Giorgio Agamben suspects. ${ }^{7}$

\section{Assembling bodies}

Still, I cannot suppress some nagging doubts about the requirement of telling a good story. My doubts seem to resonate with a familiar line of critique against the work of Hannah Arendt, Gündoğdu's main interlocutor. For Arendt, political action is actually speech. It is about citizens talking in the presence of others and being heard, about bringing forward one's point of view and winning others' approval or disapproval. To be sure, 'speech' for Arendt is not the same as language or rational expression, but refers to debate and contestation. It appeals to imagination and storytelling, not just to reason. However, the body, with its always-urgent needs, appears as a coercive or tyrannical force, that is, as an

6 Carl Schmitt, Der Begriff des Politischen (Berlin: Duncker \& Humblot, 1996), 55.

7 In particular, see: Giorgio Agamben, Homo Sacer: Sovereign Power and Bare Life (Stanford, CA: Stanford University Press, 1998); Agamben, Means Without Ends: Notes on Politics (Minneapolis, MN and London: University of Minnesota Press, 2000). 
impediment for political freedom. Because of its heavy reliance on speech, Arendt has frequently been charged with exclusivism and elitism.

The recent bodily or affective turn in post-foundational legal and political theory provides a response to this conundrum. Judith Butler, for example, in her last monograph, Notes Towards a Performative Theory of Assembly ${ }^{8}$ stresses the eminent political meaning of collective action, similar to Arendt. At the same time, she distances herself from Arendt's refusal to allow the 'precarious' body and its urgent needs a proper place in the political domain on account of the latter's allegedly rigid distinctions between social and political, respectively public and private issues and domains. As opposed to that, Butler argues that the public sphere and 'the people' are constituted, not just by speech, but more importantly by embodied collective performances, i.e., the assembling of bodies in public spaces. These assemblages should not be seen as merely pre-discursive, i.e., as merely a condition for the vocalization of claims, but as in themselves politically meaningful, she argues.

Butler's underlying concern are the operations of neoliberal privatization, i.e., the closing down of public spaces for people to assemble. Yet it is exactly the precariousness resulting from privatization that may unite otherwise disparate social movements, according to her. The Prekariat of late capitalism or neoliberalism is replacing the Proletariat of early industrial capitalism as the collective subject of public assembling. Precarity might operate 'as a site of alliance among groups of people who do not otherwise find much in common and between whom there is sometimes even suspicion and antagonism,' such as 'women, queers, transgender people, the poor, the differently abled, and the stateless, but also religious and racial minorities.' ${ }^{\prime}$ The precarious, suffering, vulnerable, dispossessed and grievable body thus becomes the political and legal subject par excellence.

However, pace Butler, I tend to agree with Gündoğdu's and Arendt's reasons to caution against absorbing the precarious body in the public domain without reserve. As Arendt observes in the case of stateless refugees, the destitute body in its 'abstract nakedness' - being reduced to the unqualified life of one who is 'nothing but human' - may command compassion or humanitarian feelings. To be pitied does, however, not mean that the rightless person is recognized as a democratic actor and a legal subject. In fact, suffering more often provokes quite the opposite response: resentment, hatred and mysophobia. 'It seems that a man who is nothing but a man has lost the very qualities which make it possible for other people to treat him as a fellow-man.' ${ }^{10}$ The suffering body may be seen as either pitiful or abject.

Following Arendt, Gündoğdu demonstrates how humanitarian resolutions of the current European refugee crisis reduce human rights issues to problems of suffer-

8 Judith Butler, Notes Towards a Performative Theory of Assembly (Cambridge, MA: Harvard University Press, 2015).

9 Butler, Notes, 27, 58.

10 Hannah Arendt, The Origins of Totalitarianism (New York: Harcourt, 1951), 299-300. 
ing bodies, which risk turning refugees into passive and speechless victims, dependent on others' unreliable affects, such as generosity or charity, or into objects of humanitarian administrative rationality and technocracy, and to constrain definitions of human rights to the basic necessities of 'bare humanity.' In this way compassion may even facilitate rightlessness, despite good intentions. I noticed that it may even backlash upon refugees, as the current public debate in Europe on the Syrian refugee crisis makes clear. If refugees are mostly seen as needy, those amongst them who are well-off are met with suspicion.

How difficult it is to circumvent the mediation of speech is manifest in Butler's example of choice of the assembly of bodies: the global Occupy movement. She held a speech during the Occupy Wall Street protests in Zucotti Park, New York, on October 23, 2011, where she said: 'As bodies we suffer, we require shelter and food, and as bodies we require one another and desire one another. So this is a politics of the public body, the requirements of the body, its movement and voice (...) $[W]$ e are here, and remain here, enacting the phrase, "we the people."11 Yet, the occupying bodies (including Butler's) were not exactly silent, nor, on the other hand, did they produce a deafening noise. Although they did not speak with one voice, and had no single spokesperson, they engaged in, yes, discourse, just like the protesting students in South Africa a few years later. Besides, I am sure that Butler would renounce cynics' refusal to make any normative distinction between different types of protest actions - say, between Occupy and the 2011 riots in London, or between the activism of Israeli settlers and the pro-Palestinian Boycott, Divestment and Sanctions campaign - although each of these examples involves assembling bodies in public space.

\section{The spectator's (lack of) enthusiasm}

How are we to decide if effective self-proclaimed human rights activism is also legitimate? When do civic protests foster human rights, and when are they merely riots? I have tried to make the case that the answers I discussed are not completely satisfactory. For liberal normative theorists, the distinction is conditional upon telling a reasonable story within given frameworks, articulations and principles of human rights, while for radical human rights skeptics any normative distinction just reflects and reinforces the status quo, whence a so-called good story is nothing but the story of the powerful. For Gündoğdu a good human rights story contains imaginative articulations, whereas Butler replaces narrating selves by assembling bodies.

I believe that these questions confront us with the problem of political judgment. More to the point, this is the problem of non-participating spectators 'who proclaim their attitude in public, ${ }^{\text {'12 }}$ not just of the actors or activists - in this case the 
students and the garbage collectors. However, political actors do not have a monopoly on the meaning and legitimacy of their actions, their audience also matters. The spectator may adopt their story - or not, or tell a different story. Like Gündoğdu and Butler, I draw my inspiration here from Arendt's work, but in a different way.

Regarding the French Revolution, the event that plays such a profound role in the European myth of the human rights discourse, Kant famously highlighted the enthusiasm of the spectators, including himself. He saw this enthusiasm, not the actions of the revolutionaries themselves, as a sign of progress of humanity. ${ }^{13}$ Arendt rejected Kant's belief in progress, but she was fascinated by his enthusiasm, for his political judgment here parallels his account of aesthetic taste. Practical judgment for Kant is 'determining': it subsumes particular cases under a given, general rule. Aesthetic judgment, on the other hand, is 'reflexive,' meaning that only the particular is given, and the rule for assessment still needs to be found. For Arendt, the latter is appropriate in our current situation, in which, as she observes, the 'thread of tradition is broken. ${ }^{14}$ She combines a firmly post-foundational stance, with a hermeneutic-phenomenological sensitivity to the situatedness of human existence and understanding in her endeavor to critically examine and come to grips with the human catastrophes that took place in her lifetime, in the middle of the 20th century. Also in our times, handed down norms and principles no longer seem to provide firm yardsticks for understanding the meaning of contemporary global problems, events and phenomena. Judging has become, as it were, lawless.

What is at stake here is the promise of Kant's aesthetic, as opposed to his practical, philosophy to do justice, both to the aspiration to leave behind mere subjectivism and partiality (informed by prejudice, petty interests and hegemonic power relations) on the one hand, and to the situatedness of judgment on the other. This is a challenging task, for judging means first of all discriminating between what is good or evil, right or wrong, true or false, beautiful or ugly, and taste plays an essential role. As our faculty for immediately discriminating between what appeals to us, elicits our enthusiasm, and what does not, taste is our most subjective and partial sensory function. While pre-reflective immediate taste judgments are hardly communicable gut feelings (de gustibus non est disputandum), it takes hard work to achieve an explicit, reflexive and independent political judgment. First, imagination and storytelling are required, the act of trying to see the world from others' points of view, by putting ourselves into their place, while being fully aware that we can never know for sure what it looks like for them. This is especially the case if those others are very differently situated, which necessitates this imaginative exercise even more so. Arendt describes this exercise as 'training one's imagination to go visiting' the plural possible perspectives of as many oth153. 
ers as possible, without suppressing one's own judgment. ${ }^{15}$ In addition, judgment also appeals to the opposite faculty of critical thinking for oneself, independent from what others may think.

Reflexive political judgments are never universally valid. Neither do they claim objective truth, as they pertain to the meaning of events. Though she can never prove that her judgment is true, the spectator strives towards winning others' approval for her point of view, hence the essential publicness of judgment. Also, our judgments are often guided by inspiring examples. A particular case or story has exemplary validity when it reveals a general meaning in its very particularity. For Arendt, the black civil rights movement in the Southern states of the U.S. of the 1950s and 1960s is such an example of human rights activism. ${ }^{16}$ The kind of validity that judgment eventually achieves refers to intersubjectivity, situated impartiality and/or exemplarity.

Although the liberal opposition party leader Mmusi Maimane called the Johannesburg waste protest a crime against humanity, because of the inconvenience - noise and smell - it caused, the majority of my neighbors with whom I discussed in the elevator saw it as precisely that - democratic discomfort - while they sympathized with the workers' struggle for a decent living standard. The student protest, on the other hand, initially met with cautious public enthusiasm in the media and in university classrooms, even among white middle-class citizens, who were reminded of the student movement for the democratization of higher education in the 1960s and 1970s in Europe and the U.S. ('1968'). However, this enthusiasm waned as soon as violence took over with the protests' resurgence in 2016.

In short, judgment does not provide firm principles or clear-cut rules, let alone the rock bottom foundation that liberal theorists often long for. Judging is a contingent and open-ended process which never produces unequivocal or final results. Political judgments, like aesthetic judgments of taste, are contextual and groundless. Yet they need not be arbitrary and subjectivist, as radical human rights critics believe. Whether particular protest actions make for a good story in the light of human rights, and succeed in translating noise and smell into discourse, is not just decided by the activists themselves but also by the spectators who judge in public. 